Utah State University

DigitalCommons@USU

1971

\title{
Introduction of Small Carpenter Bees into California for Pollination 1. Release of Pithitis smaragdula
}

Howell V. Daly

George E. Bohart

Utah State University

Robbin W. Thorp

Follow this and additional works at: https://digitalcommons.usu.edu/piru_pubs

Part of the Entomology Commons

\section{Recommended Citation}

Daly, Howell V.; Bohart, George E.; and Thorp, Robbin W., "Introduction of Small Carpenter Bees into California for Pollination 1. Release of Pithitis smaragdula" (1971). All PIRU Publications. Paper 792.

https://digitalcommons.usu.edu/piru_pubs/792

This Article is brought to you for free and open access by the Pollinating Insects Research Unit at DigitalCommons@USU. It has been accepted for inclusion in All PIRU Publications by an authorized administrator of DigitalCommons@USU. For more information, please contact digitalcommons@usu.edu.

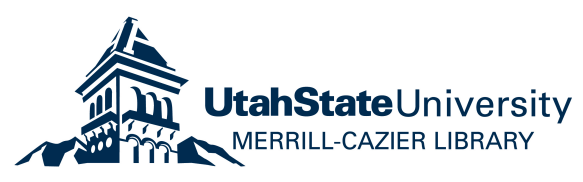


Purchased by Agricultural Research Service, U.S. Department of Agriculture, for Official Use

\title{
Introduction of Small Carpenter Bees into California for Pollination. 1. Release of Pithitis smaragdula ${ }^{1,2}$
}

\author{
Howell V. Daly, ${ }^{3}$ George E. Bohart, ${ }^{4}$ and Robbin W. Thorp ${ }^{5}$
}

\begin{abstract}
Pithitis smaragdula (F.) is a bright green, small carpenter bee which is widespread in the oriental region and is known to pollinate economically important plants, especially legumes and cucurbits. About 300 bees imported from Ludhiana, India, were released 10 April 1969, at Davis, California. Subsequent collecting during the lst season confirmed that one or more generations of the bees had been reared and that Trifolium repens $\mathbf{L}$. was visited for pollen. Although the overwintering bees under
\end{abstract}

ABSTRACT

The purpose of this paper is to record the ecological circumstances under which Pithitis smaragdula (F.) was released at Davis, Calif., and to evaluate the survival of the bees after the lst season.

Certain species of wild bees are known to be more effective than honey bees, Apis mellifera L., as pollinators of crops such as alfalfa and other forage legumes (Bohart 1957, 1958, 1960; Hobbs 1958; Lecomte and Tirgari 1965; Linsley 1946) and squash (Michelbacher et al. 1964). Until recently the only purposeful introductions of pollinating insects have been: the honey bee from the Eurasian area to many parts of the world, including California, in 1853 (Watkins 1968); the fig wasp from Smyrna, Turkey, to California in 1899 (Essig 1931); and bumble bees from England to New Zealand in 1885 (Hopkins 1914). All of these introductions were initiated before 1900 and are only partially documented. Although each is now quite successful, repeated efforts were required before the insects were established.

The feasibility and problems of introducing foreign

1 Hymenoptera: Apoidea.

2 This research supported in part by a research grant from the National Science Foundation (GB-7933). Received for publication Sept. 8, 1970 .

3 Associate Professor, Department of Entomology and Parasitology, University of California, Berkeley 94720.

${ }^{4}$ Entomologist, Entomology Research Division, Agr. Res. Serv., USDA, Logan, Utah 84321.

5 Assistant Apiculturist, Department of Entomology, University of California, Davis 95616. observation died from unknown causes, and no living bees were found in 1970 , it is possible that the bees survived elsewhere. Ecological factors believed to be important in the establishment of the colony were: few natural enemies, low competition for food, high competition for nesting sites, and a cooler, drier climate than the native habitat. Future releases are planned for warmer areas in the State.

pollinators have been discussed (Bohart 1962, Thorp 1965, Michelbacher et al. 1968). Attempts by other investigators are being made elsewhere in the world to release pollinators such as alkali bees, Nomia melanderi Cockerell, in New Zealand (P. Palmer and B. J. Donovan, DSIRO, New Zealand, personal communication) and alfalfa leafcutter bees, Megachile rotundata (F.) (but see Hurd 1967, for taxonomy), into Chile (R. Gonzalez and P. Arretz, University of Chile, personal communication), Denmark (Holm 1964), and South Australia (K. M. Doull, personal communication).

The potentiality of twig-nesting bees for manipulation as pollinators was anticipated early (Bohart 1947). These predictions were confirmed when leafcutter bees from Europe were accidentally introduced to the United States and proved to be valuable pollinators of alfalfa (Bohart 1958, Stephen and Torchio 1961). The objective of our program is to identify useful pollinators among the twig-nesting small carpenter bees, tribe Ceratinini, and to develop methods for their introduction and management. Thus far, 3 species are known to visit the flowers of economically important plants which require cross-pollination for seed production: Ceratina laevifrons Morawitiz in Central Asia, C. flavipes Smith in Japan, and $P$. smaragdula in India. Popov (1967a) noted that $C$. laevifrons visits lucerne and that populations might 
be increased by providing cut reeds for nests. Yasuo Maeta (personal communication) observed C. flavipes visiting legumes with small flowers. The agricultural importance and biology of $P$. smaragdula has been well documented by Kapil and Kurmar (1969) who list 21 crops, mainly legumes and cucurbits, visited by this species near Ludhiana, India. $P$. smaragdula was therefore chosen for the 1st purposeful release of an Old World bee to California since the importation of the honey bee.

Classification and Identification.-According to Shiokawa and Sakagami (1969), P. smaragdula is the most common and widely distributed species of the genus in the Oriental Region, being recorded at various localities from Karachi, Pakistan; and Muzaffarabad, Kashmir; to Hangchow, China; and Ambon, Indonesia. It is possible that the range extends west into Iran, since $P$. binghami Cockerell, a species often confused with $P$. smaragdula, was reported by Popov (1967b) from Kerman and Sarbaz. The genus Pithitis Klug was considered to be subgenus of Ceratina by Vecht (1952), but more recently Hirashima (1966, 1969) and Shiokawa and Sakagami (1969) have treated it as a genus. Although the bees in this genus are best known as conspicuous and colorful elements in the Oriental fauna, other species have been added from the Ethiopian fauna by Hirashima (1969).

$P$. smaragdula belongs to a group of at least 3 bright-metallic-green species (Shiokawa and Sakagami 1969, Hirashima 1969). The females of the different species are closely similar and easily confused, but the males possess distinctive features. Males of $P$. smaragdula possess a single pair of black maculations on each tergum of metasomal segments IV-VI. On closer inspection each maculation is created by a darkly melanized, nonmetallic, and deeply caniculate surface. All the males examined at the Davis site possess these maculations. When compared with the small carpenter bees (Ceratinini) in America north of Mexico, P. smaragdula is the only bright-metallicgreen species. Both sexes are shiny but coarsely and closely punctured and with yellow maculations. If seen in the field in the United States, $P$. smaragdula may superficially resemble certain native bees such as the metallic-green megachilids, e.g., Hoplitis (Chlorosmia) and some Osmia (Chenosmia), or the metallicgreen halictids, e.g., Agapostemon or Augochlorella. No other species of Apoidea in North America has black maculations created in the manner just described for the males of $P$. smaragdula.

Plant InJury.-Until the discovery that $P$. smaragdula was a valuable pollinator, the small carpenter bees were generally considered of little economic importance. Views conflicted, however, on whether the bees were beneficial as minor pollinators or injurious to plants, especially roses, as a result of their burrows in pruned stems. Over the past 15 years in the eastern United States, bees identified as Ceratina have been observed nesting in pruned stems, and their burrows have been associated with the death of the infested portions of the plants (Anonymous 1960, 1965; Bray 1964; Gesell 1961; Jones and Mitchell 1959; Negley 1968; Pepper 1955). In Russia, Popov (1967a) mentioned C. laevifrons as damaging catalpa and Ailanthus in the nurseries of Tashkent and Samarkand. Careful study has not been made of the origin and nature of the alleged damage. Although the number of species is considerably higher in the western United States, no incidents of injury to plants have been reported by growers. Otherwise, the bees are considered beneficial (Essig 1942: 712, Raghuvir et al. 1961).

As a precaution, tests were conducted at Logan, Utah, by placing the alien bees in cages over raspberry plants with both young and old canes pruned. Nesting took place, especially in the old canes, but no damage was detected; the burrows stopped when the living stem was penetrated.

Preparation for Release.-Sixty nests of $P$. smaragdula were sent from Ludhiana, Punjab, India, to Logan, Utah. The 1st shipment arrived in July 1967, and a 2nd shipment arrived in February 1969. It was not practical to follow Remington's (1968) recommendation to release wild samples directly, because alien natural enemies had to be eliminated by rearing in quarantine. In the greenhouse, cages $4 \times 2 \times 2 \mathrm{~m}$ were provided with nesting sticks about $15 \mathrm{~cm}$ long from Ailanthus altissima (Mill.) Swingle, Rhus sp., and Sambucus sp. Pollen of Phacelia sp. and Melilotus sp. was supplied as food. Copulation was observed in the cages, nests with 3-4 cells were constructed, and the 1st generation of 60 adults was $80 \%$ female.

A release site was sought in California which would (1) be near a food source including legumes; (2) have abundant nesting media of the kind already used at Logan; (3) be protected from vandalism; and (4) be in an area where interactions with native Ceratina could be observed. An isolated grove of A. altissima in the Zoology Wild Area west of the main Davis campus of the University of California was selected as meeting these requirements. Th broken dead stems of the trees provided abundant nesting sites for twig-nesting insects. The grove was situated along the North Fork of Putah Creek and occupied an area of $1872 \mathrm{~m}^{2}$ with maximum dimensions of $28 \times 82 \mathrm{~m}$. The trees ranged up to $20.3 \mathrm{~m}$ high and in some areas were sufficiently dense to provide total shade at noon in the summer. A field of Ladino clover, Trifolium repens L., was adjacent to the south side of the grove, and weedy plants such as Brassica sp., B. geniculata (Desf.) J. Ball, Centaurea solstitialis L., Convolvulus arvensis L., Datura meteloides A. DC., and Silybum marianum (L.) Gaertn. were present along the margins of the grove. One to several individual trees of $A$. altissima, as well as Sambucus sp., were scattered sparsely along the creek near the grove, but the nearest other groves of $A$. altissima were situated at distances of 0.8 and $3.2 \mathrm{~km}$.

Release and Survival.-On 10 Apr. 1969, 248 stems (6-15 mm diam, 18-36 cm long) with burrows containing hibernating bees were brought by automobile to the Davis site from Logan. The stems were divided in 16 cylindrical bundles, each tightly bound with wire. No exact count was made of the bees, since they were concealed in burrows, and it was desirable not to disturb them at the outset. Each burrow probably contained 3-4 bees at most, and the total population was probably not more than 300 . Nesting sites naturally occurring in the grove were augmented by 70 unoccupied stems of dimensions similar to the occupied stems. These were drilled at the ends with holes $3 \times 0.3 \mathrm{~cm}$ to encourage nesting, and they were bound in 10 bundles. Together with the occupied bundles, the additional stems were attached to trees with wire at about $1.5 \mathrm{~m}$ above the ground within a shaded area $15 \times 12 \mathrm{~m}$. 
Sixteen of the artificial stems, including those initially occupied and unoccupied, were dissected 2 July 1969 to estimate the progress of the introduction. Two live females of $P$. smaragdula were found with a dead female pupa in one of the original nests. The bees and the pupa probably were reared in Logan. Since few alien bees were found in the summer, an exact count of the population in the 318 artificial stems was made 6 and 18 Nov. 1969. To expedite the survey, radiographs (15 kv for 18-24 sec depending on thickness) were prepared for the 223 stems showing evidence of burrows. Since the minimum body length for museum specimens of $P$. smaragdula was $7 \mathrm{~mm}$, all stems with images of bees equal to or greater than $7 \mathrm{~mm}$ were sorted for immediate examination. This group contained all the $P$. smaragdula plus stems with larger individuals of the native Ceratina acantha Provancher. By opening the burrow at the very bottom the bees could be gently blown from the nest, identified, the nests securely closed again with pieces of wood, and the bees reintroduced at the entrance.

Four nests with a total of $28 \%$ and $7 \hat{\delta} P$. smaragdula were found in the fall plus 1 nest with $2 \%$ and 8 brood-rearing cells. The cells contained fully fed larvae, pupae, and an incomplete loaf of pollen from Trifolium repens. All the live bees were in the occupied stems originally placed in the grove. Their fresh appearance indicated that they probably were reared at Davis. A dead female and a male were found in burrows in the artificial stems which were initially unoccupied. No alien bees were found in the samples of natural stems elsewhere in the grove (see following). The 4 nests, with $21 \%$ and $6 \hat{\delta}$ of live $P$. smaragdula, were returned to the release site 4 Dec. 1969. For the next nesting season, artificial stems with ends drilled were placed in the grove 10 Feb. and 10 Mar. 1970 to provide 203 nesting sites in addition to the natural stems.

On 16 Apr. 1970, a year after the release, the 4 nests known to contain $P$. smaragdula were opened and $10 \%$ and $5 \hat{\delta}$ were recovered dead. A thorough search for survivors was undertaken on 15 June 1970 by preparing radiographs of 117 artificial stems and by dissecting 46 natural stems. No $P$. smaragdula were found in the stems. Weedy plants and nearby fields of Ladino clover and alfalfa were swept 22 July 1970 , with the result that no alien bees were collected.

Natural Enemies.-Surprisingly, no evidence of parasitoids such as the cocoons of Grotea californica Cresson or emergence holes of Eurytoma apiculae Bugbee were found in any of the collections at Davis. However, the native predators and parasites are not host-specific and some have already been recorded attacking another alien bee, Ceratina dellatorreana Friese (Daly et al. 1967).

Some very old burrows in natural stems (4, or $3 \%$ of 132 nests sampled on 23 Apr. 1969) were partly opened by the feeding activities of a vertebrate, probably a bird such as the Hairy Woodpecker. Damage of the same nature was seen on the artificial stems collected in the fall (3, or $1.8 \%$ of 223 nests sampled on 6 and 18 Nov. 1969). The arrangement in bundles limited the exposure to this enemy to the outer stems but at the same time provided a refuge for insects and spiders among the inner stems. When the bundles were observed in the summer, spider webs were common, and aestivating Hypera brunneipennis Boheman were seen among the stems and obstructing the entrances of burrows. When all bundles were opened 6 and 18 Nov. 1969, $1 \%$ and $1 \hat{\delta}$ P. smaragdula and $4 \%$ and $1 \hat{\circ}$ C. acantha were found dead and entangled in spider webs. They were probably victims of Phidippus sp. or the reduviid Zelus renardii Kolenati which were found in the bundles. The artificial stems deposited in the grove in 1970 were arranged side-by-side in a raftlike manner to reduce shelter for predators and to facilitate the preparation of radiographs.

The dead $P$. smaragdula which were recovered from nests on 16 Apr. 1970, exhibited no injuries, but were examined for pathogens. Only the following saprophytic fungi were detected: Cladosporium sp., Penicillium sp., and Rhizopus nigricans Ehrenberg.

Competition fOR Nests and Food.-The establishment and management of $P$. smaragdula was expected to depend largely on its ecological relationships with twig-nesting bees and wasps, especially Ceratina. Release in the Great Valley of California has certain advantages, since the bee fauna is reduced in numbers of species when compared with the adjacent mountainous regions (Hurd and Michener 1955, Daly 1966b). While the latter have at least 10 species of native Ceratina, only 2 native species, $C$. acantha and $C$. arizonensis Cockerell, and the alien $C$. dallatorreana are commonly collected at Davis. This is probably because portions of the Valley were occupied by the sea during much of the Tertiary (Bailey 1966), and until agricultural activities began the native vegetation was largely tule marshes and steppe (Küchler 1964).

Both native species are polylectic: $C$. acantha has been collected from the flowers of 109 genera of plants (6 in Leguminosae) and $C$. arizonensis from 43 genera (2 in Leguminosae). The Mediterranean C. dallatorreana is largely limited to the Great Valley and is polylectic, having been taken in California on 5 genera, each in a different plant family ( 1 in Leguminosae). Although a taxonomically wide variety of plants serve as nesting media in the Great Valley, the same plant species are commonly used by 2 or more of the prevalent species of small carpenter bees: A. altissima, Artemisia sp., Brassica sp., Foeniculum vulgare Mill., Rubus sp., Rumex sp., and Sambucus sp.

P. smaragdula is well known in the Oriental region as a polylectic bee which readily visits introduced species for food and also nests in a wide assortment of plants (Iwata 1938, Rahman 1940, Vecht 1952, Sakagami and Yoshikawa 1961, Shiokawa and Sakagami 1969). Based on our identification of voucher specimens at the University of Kansas, Lawrence, $P$. smaragdula was reported as Ceratina binghami Cockerell by Batra (1967). In her study, the bees were recorded from flowers of 21 species of plants (4 in Leguminosae) at Ludhiana, India. Kapil and Kumar (1969) provided a host list of 21 economically important plants including 8 legumes.

Since the small carpenter bees already resident in the Great Valley visit legumes infrequently, their competition for food with $P$. smaragdula is likely to be negligible. An analysis of 7 loaves from 5 nests of C. acantha at the Davis site revealed pollen from the following plants in decreasing order of abundance: Brassica sp., Cirsium sp. or Silybum sp., Convolvulus sp., and minor amounts from Asterae and Leguminosae.

The most plentiful nesting media are already 
shared by the resident species, and competition for nesting sites can be expected. Some evidence exists, for example, that the spread of $C$. dallatorreana outside the Valley tends to be limited by the presence of native Ceratina (Daly 1966a). Because of their similar body size, $C$. acantha and $C$. dallatorreana are most likely to be the competitors with $P$. smaragdula for nests.

Both $C$. acantha and $C$. arizonensis were present at the Davis site, but only $C$. acantha was found nesting within the grove. A sample of 132 natural stems with burrows was taken 23 Apr. 1969, shortly after the release of alien bees. Of these 108 , or $81.8 \%$, were occupied by a total of $124 \%$ and $16 \hat{\delta} C$. acantha, and 1 stem was occupied by adults of $A n$ cistrocerus spilogaster Cameron. The female bees were evidently dispersing from overwintering aggregations in the parental nests and seeking suitable stems for their own nests. Ordinarily, new nests are excavated, but only 35 of the 108 were clearly fresh, and 30 were possibly parental nests being reused. The remaining occupied stems included 11 with evidence of old nests of Trypoxylon sp. and 32 very old, partly decayed burrows. The latter are never seen later in the year with brood. Among the empty burrows, 19 appeared suitable for nests. In all, only 95 burrows plus an unknown number of unexploited stems were available for the $124 \%$ in the sample. We believe the unexploited stems are rather few and that more female $C$. acantha survive the winter than can be accommodated by nesting sites in the spring. This suspicion is born out by the overwhelming invasion of the artificial nests discussed below. Another indication of competition for nests was the discovery of 1 nest of 3 o with a fresh, incomplete loaf of pollen, and 3 nests, each with 2-3 o bees and 1 or more freshly completed cells. These were the only nests showing brood production. Ordinarily, only 1 $q$ is present in the nest when provisioning and cell construction are initiated. However, these exceptional instances may be cases of nest supersedure in progress.

When the 16 artificial stems were examined 2 July $1969, C$. acantha had established 8 nests with brood. By 6 and 18 Nov. 1969, 118 or $52.9 \%$ of the 223 artificial stems with burrows were occupied with a total of 646 o and $260 \hat{\delta}$. The artificial stems which were invaded included 155 burrows originally excavated by $P$. smaragdula as well as 68 or $97.1 \%$ of the extra 70 placed in the grove. Although only 32 or $47 \%$ of the 68 still were occupied, virtually all can be attributed to $C$. acantha, since no evidence exists that $P$. smaragdula used the new stems for nests. The whole collection of artificial nests also included evidence of Trypoxylon bidentatum Fox (det. A. S. Menke) in 57. Of these, 11 had $C$. acantha as secondary residents and 13 each had a larva of Cymatodera ovipennis LeConte (det. F. D. Parker) which is presumably predaceous on the immature wasps. Other insects in the burrows included Agulla sp. and Hypera brunneipennis. Also in the fall, 52 natural stems with burrows were examined and 20 or $38.4 \%$ were occupied with a total of $125 \%$ and $51 \delta$ of $C$. acantha. None of the $C$. acantha were returned to the grove to reduce the population competing with $P$. smaragdula.

In spite of the removal of 771 o and $311 \hat{o}$ in the fall of 1969, radiographs of 117 artificial stems on 15 , 16 June 1970 revealed at least 69 or $58.9 \%$ with burrows and 66 of these occupied by 56 bees and brood of $C$. acantha. Dissection of 46 natural stems with burrows revealed 28 or $60.9 \%$ occupied with a total of 33 q and $1 \hat{\delta}$.

Physical Environment.-Judged by the descriptions of the climate at Ludhiana by Batra (1967), Kapil and Dhaliwal (1968), and Kapil and Kumar (1969), the alien bees were subjected to changes in the distribution and magnitude of temperature and rainfall. Ludhiana has a semiarid, subtropical climate with a summer monsoon (average annual rainfall $78.39 \mathrm{~cm})$. Davis has a mediterannean climate with a wet winter (average annual rainfall $42.16 \mathrm{~cm}$ ). A comparison of estimated temperatures from the weather graph provided by Kapil and Dhaliwal (1968) with 1969-70 temperatures at Davis shows that Davis is cooler throughout the year. The average maximum monthly temperatures during October to March ranged $7-10^{\circ} \mathrm{C}$ cooler, and the average minimum monthly temperatures were $6-9^{\circ} \mathrm{C}$ cooler at the beginning and end of this period. During December and January the differences between the average minimum temperatures were negligible, but Davis had a total of 15 days below $0^{\circ} \mathrm{C}$ (lowest $-4^{\circ} \mathrm{C}$ ) from late November to early January while the lowest temperature at Ludhiana reported by Kapil and Kumar (1969) was $0.2^{\circ} \mathrm{C}$. The average maximum monthly temperatures during April to June range $8-12^{\circ} \mathrm{C}$ cooler at Davis with the greatest difference in June when temperatures at Ludhiana exceed $40^{\circ} \mathrm{C}$. The average minimum monthly temperatures during April to June range 9 to $17.5^{\circ} \mathrm{C}$ cooler at Davis with the greatest difference also in June. During July to September the average maximum monthly temperatures range $1-4.5^{\circ} \mathrm{C}$ cooler at Davis and the average minimum monthly temperatures $10.5-19.8^{\circ} \mathrm{C}$ cooler with the largest difference in September.

Discussion.-One or more generations were probably produced during the 1 st season because the average adult life for overwintering bees is expected to range from 74 to 110 days (Kapil and Kumar 1969), while the surviving fall population at Davis, 210-222 days after release, had fresh unworn wings.

Most of the bees probably dispersed from the site shortly after their release. The disturbance during transportation and their reported migratory habit (Kapil and Kumar 1969) may have contributed to an early reduction in population in the area sampled. Since some may have been inseminated, it is possible that the bees constructed nests and reproduced elsewhere. Those remaining at the release site apparently did not invade natural stems, and no live bees were discovered outside the original nests. The grove was free of natural enemies which attack immature stages and was well supplied with nesting media. However, a large population of $C$. acantha occupied most of the natural stems and quickly utilized the artificial stems intended for $P$. smaragdula. Therefore, competition for nests with this native bee and to a lesser extent with Trypoxylon sp. was probably an important factor in the early establishment of the alien bees. Competition for food with the native species of Ceratina is believed to have been insignificant, and other kinds of bees visiting legumes were probably not sufficiently numerous to have been limiting. Some alien bees were evidently eaten by spiders, predaceous insects, and possibly by birds. The rate of development of the immature stages was doubtless slower at Davis because of the cooler climate and the shaded 
release site. During 8 months at Ludhiana, 6-7 generations are passed by $P$. smaragdula (Kapil and Kumar 1969) in comparison with 1-2 generations passed by native Ceratina sp. in California. The observed winter mortality of the alien bees is most likely not from disease, but probably from injuries suffered during the sampling procedures in the fall, life history not synchronized with the new seasons, or freezing temperatures. The last may not be critical, because the geographic range of $P$. smaragdula includes areas of northern India and Kashmir where freezing occurs. Future releases are planned for warmer portions of the State.

ACKNOWLEDGMENT.-We express appreciation to Dr. R. P. Kapil, formerly Senior Research Officer, and to Dr. A. S. Atwal, Punjab Agricultural University, Ludhiana, India, for providing the living bees used in this introduction. Thanks are due $\mathrm{Mr}$. Yasuo Maeta and Dr. S. W. T. Batra for their diligent supervision of the colony at Logan, Utah, and Mr. Philip F. Torchio for transporting the bees to Davis. After the release, Mr. Dennis Briggs, University of California at Davis, and Mr. Larry Boulet, University of California at Berkeley, assisted in the field and laboratory studies. We are especially grateful to Mr. Lloyd E. Browne, University of California, Berkeley, who prepared the radiographs of the nests, and to Dr. George O. Poinar and Gerard M. Thomas of the same institution, who examined the bees for pathogens. Dr. R. M. Bohart, University of California at Davis, kindly identified the wasps.

\section{REFERENCES CITED}

Anonymous. 1960. A carpenter bee (Ceratina sp.). Plant Pest Control Div. USDA Coop. Econ. Insect Rep. $10(42): 982$

1965. A carpenter bee (Ceratina dupla). Ibid. 15 (16) : 371.

Bailey, E. H. 1966. Geology of Northern California. Calif. Div. Mines and Geol. Bull. 190. 507 p.

Batra, S. W. T. 1967. Crop pollination and the flower relationships of the wild bees of Ludhiana, India (Hymenoptera, Apoidea). J. Kans. Entomol. Soc. 40 (2) : 164-77.

Bohart, G. E. 1947. Wild bees in relation to alfalfa pollination. Farm and Home Science, Utah Agr. Exp. Sta. 8(4): 13-14.

1957. Pollination of alfalfa and red clover. Annu. Rev. Entomol. 2: 355-80.

1958. Alfalfa pollinators with special reference to species other than honey bees. Proc. 10th Int. Congr. Entomol. (1956) 4: 929-37.

1960. Insect pollination of forage legumes. Bee World 41: 57-64, 85-97.

1962. Introduction of foreign pollinators, prospects and problems. Proc. First Int. Symp. Pollination (Copenhagen, 1960), p. 181-8.

Bray, D. F. 1964. A carpenter bee (Ceratina sp.) Plant Pest Control Div. USDA, Coop. Econ. Insect Rep. 14 (19): 445.

Daly, H. V. 1966a. Biological studies on Ceratina dallatorreana, an alien bee in California which reproduces by parthenogenesis (Hymenoptera: Apoidea). Ann. Entomol. Soc. Amer. 59: 1138-54.

1966b. Distributional patterns of bees of the genus Ceratina. Bull. Entomol. Soc. Amer. 12: 114

Daly, H. V., G. I. Stage, and T. Brown. 1967. Natural enemies of bees of the genus Ceratina (Hymenoptera: Apoidea). Ann. Entomol. Soc. Amer. 60: 1273-82.

Essig, E. O. 1931. A History of Entomology. Macmillan Co., New York. 1029 p.

1942. College Entomology. The Macmillan Co., New York. $900 \mathrm{p}$.
Gesell, S. G. 1961. A leaf-cutting bee (Ceratina dupla) Plant Pest Control Div. USDA. Coop. Econ. Insect Rep. $11(26): 581$

Hirashima, Y. 1966. Comments on the genus Pithitis Klug with record of a species new to the Philippines (Hymenoptera, Anthophoridae). Kontyû 34 (4) : 315-6.

1969. Synopsis of the genus Pithitis Klug of the world (Hymenoptera: Anthophoridae). Pac. Insects 11 (34) : 649-69.

Hobbs, G. A. 1958. Factors affecting value of bees (Hymenoptera: Apoidea) as pollinators of alfalfa and red clover. Proc. Tenth Int. Congr. Entomol. (1956) 4: $939-42$.

Holm, S. N. 1964. Bladskaerebein (Megachile rotundata). Ugeskrift for Landmaend no. 45,6 Nov. $3 \mathrm{p}$.

Hopkins, I. 1914. History of the Humble bee in New Zealand: Its introduction and results. N.Z. Dep. Agr., Indust., and Commerce Bull. (new series) . 46: 3-29.

Hurd, P. D., Jr. 1967. The identity of Megachile rotundata (Fabricius) and $M$. argentata (Fabricius) (Hymenoptera:Apoidea). Entomol. Medd. 35: 3-10.

Hurd, P. D., Jr., and C. D. Michener. 1955. The megachiline bees of California (Hymenoptera:Megachilidae). Bull. Calif. Insect Surv. 3: 1-247.

Iwata, K. 1938. Habits of some bees in Formosa. III. [In Japanese, translation in Sakagami and Yoshikawa 1961]. Trans. Nat. Hist. Soc. Formosa 28: 257-62.

Jones, G. D., and T. B. Mitchell. 1959. A carpenter bee (Ceratina sp.). Plant Pest Control Div. USDA, Coop. Econ. Insect Rep. 9 (38) : 868.

Kapil, R. P., and J. S. Dhaliwal. 1968. Biology of Xylocopa species. I. Seasonal activity, nesting behaviour and life cycle. J. Res. Punjab Agr. Univ. $5(3)$ : 406-19.

Kapil, R. P., and S. Kumar. 1969. Biology of Ceratina binghami Ckll, (Ceratinini:Hymenoptera). Ibid. $6(2): 359-71$.

Küchler, A. W. 1964. Potential natural vegetation of the conterminous United States. Amer. Geogr. Soc., Spec. Publ. no. 36, Manual and Map.

Lecomte, J., and S. Tirgari. 1965. Sur quelques pollineateurs des Legumineuses fourragères. Ann. Abeille (Paris) 8: 83-93.

Linsley, E. G. 1946. Insect pollinators of alfalfa in California. J. Econ. Entomol. 39: 18-29.

Michelbacher, A. E., P. D. Hurd, Jr., and E. G. Linsley. 1968. The feasibility of introducing squash bees (Peponapis and Xenoglossa) into the Old World. Bee World 49: 159-67.

Michelbacher, A. E., R. F. Smith, and P. D. Hurd, Jr. 1964. Bees are essential ... pollination of squashes, gourds and pumpkins. Calif. Agr. 18: 2-4.

Negley, F. B. 1968. A carpenter bee (Ceratina dupla). Plant Pest Control Div. USDA. Coop. Econ. Insect Rep. $18(40)$ : 947.

Pepper, J. O. 1955. A carpenter bee (Ceratina dupla). Ibid. 5 (25) : 579

Popov, V. B. 1967a. Wild bees (Hymenoptera, Apoidea) of Central Asia and their relationships to flowering plants [In Russian]. Akad. Nauk SSSR, Leningrad, Zool. Inst., Tr. 38: 11-329.

1967b. The bees (Hymenoptera, Apoidea) of Iran [In Russian]. Ibid. 43: 184-216.

Raghuvir, W. N., D. W. Davis, G. F. Knowlton. 1961. A bee (Ceratina acantha submaritima). Plant Pest Control Div. USDA. Coop. Econ. Insect Rep. 11 (47) : 1060.

Rahman, K. A. 1940. Insect pollinators of toria (Brassica napus L., var. dichotoma Prain) and Sarson ( $B$. campestris L., var. sarson Prain) at Lyallpur. Indian J. Agr. Sci. 10: 422-47.

Remington, C. L. 1968. The population genetics of insect introduction. Annu. Rev. Entomol. 13: 415-26.

Sakagami, S. F., and K. Yoshikawa. 1961. Bees of Xylocopinae and Apinae collected by the Osaka City University Biological Expedition to Southeast Asia 
1957-58, with some biological notes. Nature Life Southeast Asia 1: 409-44.

Shiokawa, M., and S. F. Sakagami. 1969. Additional notes on the genus Pithitis or green metallic small carpenter bees in the Oriental Region, with descriptions of two species from India. Ibid. 6: 139-51.

Stephen, W. P., and P. F. Torchio. 1961. Biological notes on the leafcutter bee, Megachile (Eutricharaea) rotundata (Fabricius) (Hymenoptera: Megachilidae). Pan-Pac. Entomol. 37 (2) : 85-93.
Thorp, R. W. 1965. The development of commercial wild bee pollination in the West. Seventh Bee Pollination Conf., College Station, Texas, Abstracts. p. 11-13.

Vecht, J. van der. 1952. A preliminary revision of the Oriental species of the genus Ceratina (Hymenoptera, Apidae). Zool. Verh. Rijksmus. Natuur. Hist. Leiden. 16: $1-85$.

Watkins, L. H. 1968. California's first honey bees. Amer. Bee J. 108 (5) : 190-1.

\section{Reprinted from the}

Journal of ECONOMIC ENTOMOLOGY

Volume 64 , Number 5, pp. 1145-1150, October 1971 